\title{
Loss of MDC1 in Endometrial Carcinoma Is Associated With Loss of MRN Complex and MMR Deficiency
}

\author{
DANAE MERENTITIS ${ }^{1 *}$, BICH DOAN NGUYEN $^{1 *}$, ELEFTHERIOS P. SAMARTZIS $^{1}$, \\ AURELIA NOSKE ${ }^{2}$, SIMONE BRANDT ${ }^{2}$ and KONSTANTIN J. DEDES ${ }^{1}$ \\ ${ }^{1}$ Department of Gynecologic Oncology, University Hospital of Zurich, Zurich, Switzerland; \\ ${ }^{2}$ Institute of Pathology, University Hospital of Zurich, Zurich, Switzerland
}

\begin{abstract}
Aim: To evaluate the frequency of loss of mediator of DNA damage checkpoint protein 1 (MDC1) protein expression in endometrial cancer (EC) and to determine whether loss of MDCl is associated with certain clinicopathological parameters. Materials and Methods: $M D C 1$ expression was examined in 426 samples of EC. The nuclear immunoreactivity of the protein was defined as: negative, weak, moderate and strong. Results: Loss of MDC1 expression (defined as negative nuclear staining) was found in $8.9 \%$ (38/426) of ECs and was significantly associated with the loss of MRE11 homolog, double-strand break repair nuclease, RAD50 double-strand break repair protein and nibrin complex components. In addition, loss of expression of MDCl showed a significant correlation with any mismatch repair deficiency, with endometrioid histological subtype and low tumour grading. Conclusion: Based on these findings, we suggest that MDC1 loss frequently occurs in ECs with microsatellite instability. Due to deficient homologous recombination DNA repair, MDC1-negative ECs might show an increased sensitivity to poly(ADP-ribose) polymerase-inhibitory therapy.
\end{abstract}

Endometrial cancer (EC) is the most common gynecologic carcinoma in developed countries and the fourth most common neoplasm among women worldwide $(1,2)$. The vast majority presents at an early stage (75\%) (3) with a relatively favourable prognosis (4). Treatment options, however, for advanced, recurrent or metastatic ECs, are limited and consist mainly of cytotoxic chemotherapy. There are a large

\footnotetext{
*These Authors contributed equally to this study.

Correspondence to: PD Dr. Konstantin Dedes, University Hospital of Zurich, Frauenklinikstrasse, CH-8091 Zurich, Switzerland. E-mail: konstantin.dedes@usz.ch
}

Key Words: MDC1, endometrial carcinoma, PARP, mismatch repair, targeted therapy. number of gene abnormalities as well as aberrant signaling pathways such as phosphatidylinositol-4,5-bisphosphate 3kinase catalytic subunit alpha (PIK3CA)/ phosphatase and tensin homolog (PTEN)/AKT serine/threonine kinase (AKT)/ mechanistic target of rapamycin kinase (mTOR) that appear to be promising targets but clinical studies are lacking. Recently, potential targeted treatments such as the immune checkpoint inhibitor pembrolizumab in patients with microsatellite instability (MSI)-high EC have been incorporated in clinical use $(5,6)$.

ECs are classified into two types based upon clinicopathological features and their clinical prognosis (79). Type I neoplasms are low-grade endometrioid ECs (10). They are stimulated by estrogens, patients present with them at an early stage and have a good prognosis (11). Endometrioid type accounts for the majority of ECs $(90 \%)$ (12). Type II neoplasms are grade 3 endometrioid ECs and non-endometrioid tumours such as serous or clear cell carcinoma $(12,13)$. In addition, these two categories are characterized by their specific molecular aberrations which occur preferentially either in type I or type II ECs (9). Type I cancer harbours MSI as well as polymutations in different types of genes whereas p53 mutations occur more common in type II ECs $(14,15)$.

Studies from the Cancer Genome Atlas classified 373 ECs into four genomic subtypes based upon their copy-number changes and genomic profile: DNA polymerase epsilon (POLE) ultramutated, MSI hypermutated, copy-number-low and the copy-number-high subgroups (16). The hypermutated subtype includes mostly endometrioid ECs, all harbouring MSI (16). These types of cancer are known to harbour mutations in other different genes (hypermutated genome) such as those participating in the DNA double-strand break repair mechanisms (17).

In the past few years, molecular-targeted cancer therapies have been developed, making use of the phenomenon of synthetic lethality (18). Nearly a hundred years ago, Bridges first described the concept of synthetic lethality (19). Synthetic lethality between two genes arises when an 
alteration in the expression of either of them leads to a phenotype that is compatible with viability, whereas concurrent inhibition of both genes causes cell death (20). To implement this idea, cancers incorporating a synthetic lethal mutation have to be identified in order to target the synthetic lethal partner gene. One of the most beneficial features of such a specific anticancer drug is that it does not affect healthy tissue (21).

Recently, it was postulated that cancer cells which harbour deficiency of homologous recombination (HR) DNA-repair mechanisms have an increased sensitivity to poly(ADPribose) polymerase (PARP) inhibitors $(22,23)$. Inhibition of PARP1 enzymatic activity leads to an accumulation of single-strand breaks that are converted to double-strand breaks but cannot be repaired by HR. Inhibition of PARP has therefore been advanced as a novel targeted therapy for cancers harbouring breast cancer $1 / 2(B R C A 1 / 2)$ mutations (24). One of the most common mutations is found in the MRE11 homolog, double-strand break repair nuclease (MRE11), whose product is a part of the MRE11-RAD50 double-strand break repair protein (RAD50)-nibrin (NBN) (MRN) complex that is involved in the detection and repair of DNA double-strand breaks $(25,26)$. In a previous report we showed that not only the expression of MRE11 but also the expression of the other MRN complex components RAD50 and NBN is lost in $30.7 \%$ of ECs. Furthermore, we observed a significant association between loss of MRN components and mismatch repair (MMR) status in ECs. A decrease in MRE11 expression and function led to increased sensitivity towards PARP inhibition in EC cell lines (22). Recent studies have shown that mediator of DNA damage checkpoint protein 1 (MDC1) is a participant in the early response to DNA damage and its subsequent signaling within cells. Its co-localization with BRCA1 is suggestive of a role in homologous recombination.

MDC1 plays an important role in the DNA double-strand break repair machinery by being part of two important DNA repair pathways: the non-homologous end-joining response and $\operatorname{HR}(27,28)$. The aim of the study was to evaluate the frequency of loss of MDC1 protein expression in ECs and to examine whether loss of MDC1 is associated with clinicopathological features and MMR protein status in EC.

\section{Materials and Methods}

EC sample characteristics. Tissue microarrays (TMAs) of formalinfixed and paraffin-embedded ECs were assembled as previously published $(22,29)$, containing samples of two cohorts from the Institutes of Surgical Pathology, University Hospital Basel and Zurich (Switzerland), containing 339 (Basel-TMA) and 182 (ZurichTMA) cancer samples in total. The study was approved for both cohorts by the local Scientific Ethics Committee (KEK-ZH-NR: 2010-0358). In the present study, a total of 426 EC samples were available for further analysis due to tissue loss in some TMA spots.
Table I. Clinical characteristics of patients with endometrial carcinoma.

\begin{tabular}{lc}
\hline Variable & $\mathrm{n}(\%)$ \\
\hline Age at diagnosis & \\
$\leq 68$ Years & $218(52.3)$ \\
$>68$ Years & $199(47.7)$ \\
Unknown & $9(2.1)$ \\
FIGO stage & \\
I & $213(50.0)$ \\
II & $54(12.7)$ \\
III & $70(16.4)$ \\
IV & $14(3.3)$ \\
Unknown & $75(17.6)$ \\
Histological subtype & \\
Endometrioid & $355(83.3)$ \\
Mucinous & $3(0.7)$ \\
Serous & $31(7.3)$ \\
Clear cell & $14(3.3)$ \\
Carcinosarcoma/MMMT & $13(3.1)$ \\
Undifferentiated & $10(2.3)$ \\
Endometrioid (incl. mucinous) & $358(84)$ \\
Non-endometrioid & $68(16)$ \\
Grading & \\
1 \& 2 & $312(73.2)$ \\
3 & $114(26.8)$ \\
\hline
\end{tabular}

FIGO: Fédération Internationale de Gynécologie et d'Obstétrique; MMMT: malignant mixed Müllerian tumor.

Clinical and pathological characteristics were taken from the clinical databases and pathology records. Routine hematoxylin and eosin sections were performed for histopathological evaluation. The stage of tumours was assessed according to the International Federation of Gynaecology and Obstetrics (FIGO) and TNM staging system. Histological subtype and tumour grade were defined according to the WHO classification 2014. Follow-up data are known from 480 patients. The median follow-up time was 31.5 (range=1-184) months for the Basel cohort, and 45 (range=1-124) months for the Zurich cohort. Baseline characteristics of patients with endometrial cancer are summarized in Table I.

Immunohistochemistry. After antigen retrieval, the slides were incubated with an antibody against MDC1 for 1 hour at room temperature. The antibodies against MDC1 (rabbit polyclonal, 1:250) were obtained from Bethyl Laboratories (Montgomery, TX, USA) and LubioScience (Zurich, Switzerland). The staining was conducted with a Ventana Benchmark automated system (Ventana Medical Systems, Tucson, AZ, USA) using Ventana reagents as well as UltraMap ${ }^{\mathrm{TM}}$ DAB detection kit (Ventana Medical Systems, Tucson, AZ, USA). The microscopic analysis of the staining was independently performed by two pathologists (SB, AN). We observed nuclear immunoreactivity of MDC1 and scored the intensity of nuclear expression as following: Negative, weak, moderate and strong. The protein expression of the MMR genes was considered as positive when nuclear staining was evident and negative when complete loss of nuclear staining was observed. Stromal cells showing nuclear staining were used as a positive control. 

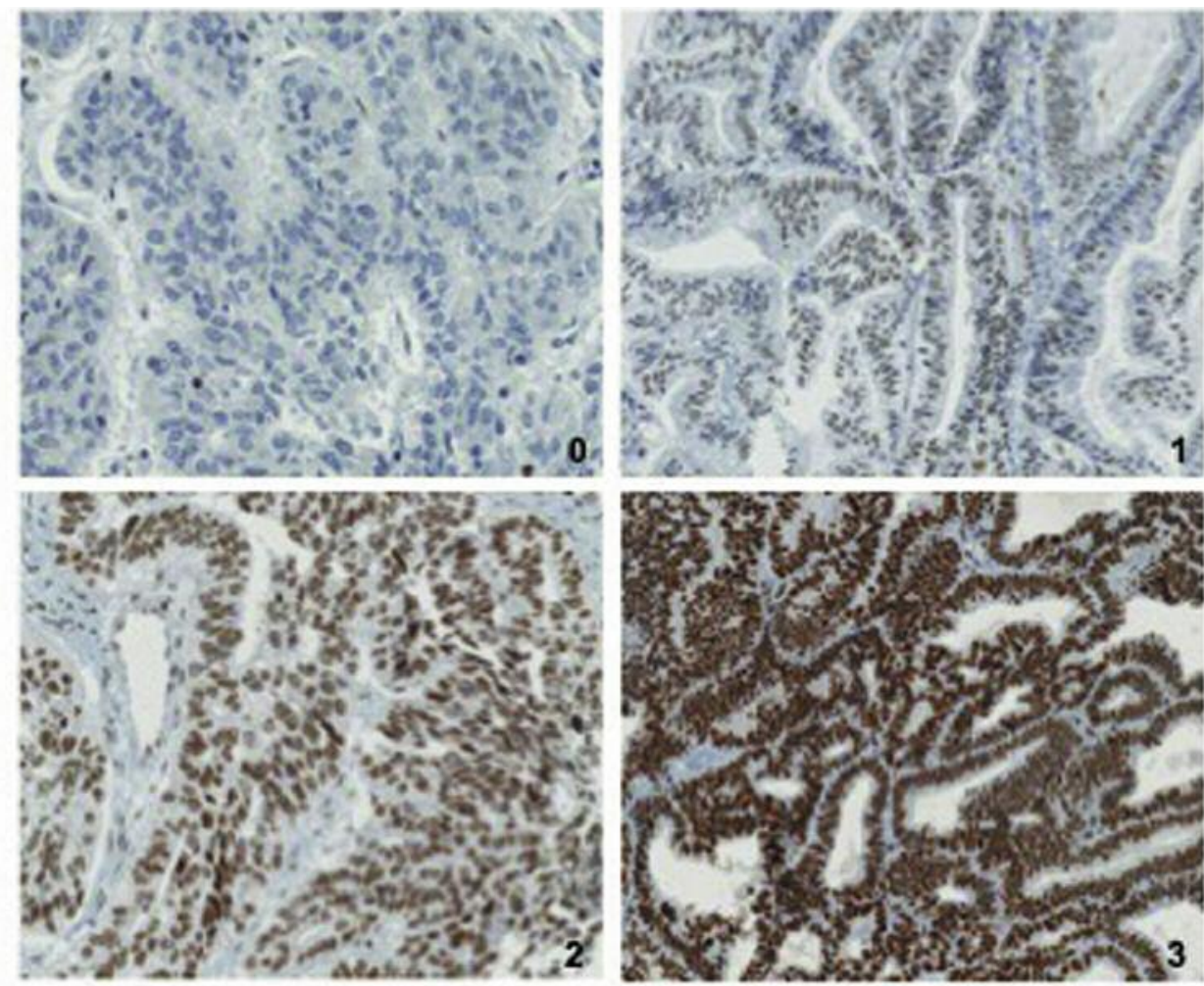

Figure 1. Expression of mediator of DNA damage checkpoint 1 (MDC1) protein in endometrial carcinomas as assessed by immunohistochemistry (magnification: ×20). 0: Negative (complete loss of MDC1 protein expression). 1: Weak nuclear expression. 2: Moderate nuclear expression. 3: Strong nuclear expression. Representative images are shown.

Statistical analysis. The statistical evaluation was performed with SPSS software Version 21.0 (IBM, Armonk, NY, USA). The scoring data of MDC1 were dichotomized into negative (no expression) and positive (any expression, weak to strong). The statistical significance of the association with MMR protein expression, MRE11, RAD50, and NBN, as well as clinicopathological parameters, was assessed by chi-squared test for trends and Fisher's exact test. Differences in survival curves were compared by the logrank test. Generally, $p$-values of less than 0.05 were considered as significant.

\section{Results}

MDC1 protein expression. Immunohistochemical analysis of MDC1 of a total of 426 EC samples was performed. Representative images of the different expression patterns are shown in Figure 1. We found 38 negative cases, 85 weak positive, 203 moderate and 100 strong positive cases. The results were further grouped into negative and positive staining. A total of $388(91.1 \%)$ EC samples showed positive staining for MDC1, 38 (8.9\%) showed no nuclear immunoreactivity.

Association of MDCl with clinicopathological characteristics. MDC1 negative cases were significantly associated with the endometrioid subtype (including mucinous) as compared with the non-endometrioid subtype (serous, clear-cell, carcinosarcoma and undifferentiated) $(p=0.018)$ and occurred more often in grade 1 and 2 tumours than in grade 3 tumours $(p=0.02)$ as shown in Table II. No association with FIGO stage or patient age was observed.

Association of MDC1 with MMR protein status and MRN complex proteins. In a previous study, we investigated MMR protein status mutL homolog 1 (MLH1), mutS homolog 2 (MSH2), mutS homolog 6 (MSH6), PMS1 homolog 2, mismatch repair system component (PMS2) and MRN complex proteins like MRE11, RAD50, and NBN in this EC cohort (22). Since MDC1 plays a role in DNA repair, we were interested in looking for an association between MDC1 and MMR, as well as MRN status. The expression of MMR proteins was considered as positive when nuclear staining was evident. Stromal cells showing nuclear staining were used as a positive control. MMR deficiency was defined as negative nuclear staining for any of the evaluated MMR proteins (MLH1, PMS2, MSH2 or MSH6). Negativity for MDC1 was more frequently observed in carcinomas with MMR deficiency $(\mathrm{n}=27, p=0.0001)$. 
Table II. Immunohistochemical expression of mediator of DNA damage checkpoint 1 (MDC1), MRE11 homolog, double-strand break repair nuclease (MRE11), RAD50 double-strand break repair protein (RAD50), nibrin (NBN) mismatch-repair (MMR) proteins.

\begin{tabular}{llc}
\hline Marker & Expression & $\mathrm{n}(\%)$ \\
\hline MDC1 $(\mathrm{n}=426)$ & Negative & $38(8.9)$ \\
& Positive & $388(91.1)$ \\
MRN complex $(\mathrm{n}=414)$ & Negative & $167(40.3)$ \\
& Positive & $247(59.7)$ \\
MRE11 (n=415) & Negative & $132(31.8)$ \\
& Positive & $283(68.2)$ \\
RAD50 $(\mathrm{n}=419)$ & Negative & $101(24.1)$ \\
& Positive & $318(75.9)$ \\
NBN $(\mathrm{n}=416)$ & Negative & $127(30.5)$ \\
& Positive & $289(69.5)$ \\
Any MMR deficiency $(\mathrm{n}=391)$ & Negative & $178(45.5)$ \\
& Positive & $213(54.5)$ \\
\hline
\end{tabular}

Furthermore, an association of carcinomas with negative MDC1 immunohistochemistry and loss of nuclear protein expression of the evaluated MRN complex proteins MRE11 $(\mathrm{n}=25, p=0.0001), \operatorname{RAD} 50 \quad(\mathrm{n}=16, p=0.007)$ and NBS1 $(\mathrm{n}=29, p=0.0001)$ were demonstrated (shown in Table III).

MDCl expression and impact on overall survival in patients with ECs. In univariate Kaplan-Meier analysis, FIGO stage, histological subtype, grading and patient age were prognostic factors for overall survival (log-rank, $p<0.0001$ for all parameters). However, the expression of MDC1 (log rank, $p=0.110$ ) was not associated with overall survival.

\section{Discussion}

Cells are continuously exposed to agents that lead to DNA damage, which, if not repaired effectively and efficiently, can result in genomic instability. The HR pathway plays an important role in this context. HR-deficient tumours have been reported widely in literature, including ovarian and breast cancer $(30,31)$.

In mice, mutation of $M d c l$ causes impaired spermatogenesis, as well as other disorders due to genomic instability (32). Because of its role as a potential tumour suppressor, loss of MDC1 expression has been described in various types of neoplasms such as breast, lung (33) and gastric carcinoma (34). Besides being part of HR $(14,15), \mathrm{MDC} 1$ contributes to the DNA damage-response pathway by managing the activation of the intra-S-phase and $\mathrm{G}_{2} / \mathrm{M}$ phase cell-cycle checkpoints in the case of DNA damage $(35,36)$. After exposure of cells to ionizing radiation and other factors as UV irradiation and endogenous damage, MDC1 mediates the recruitment of several DNA-repair proteins to the site of damaged DNA. These DNA
Table III. Association of expression of mediator of DNA damage checkpoint 1 (MDC1) with clinicopathological features, and components of the MRE11 homolog, double-strand break repair nuclease (MRE11)-RAD50 double-strand break repair protein (RAD50)-nibrin (NBN) (MRN) complex.

\begin{tabular}{|c|c|c|c|}
\hline \multirow[b]{2}{*}{ Variable } & \multicolumn{2}{|c|}{$\mathrm{MDC} 1, \mathrm{n}$} & \multirow[b]{2}{*}{$p$-Value } \\
\hline & Negative & Positive & \\
\hline \multicolumn{4}{|l|}{ Histological subtype } \\
\hline Endometrioid & 37 & 318 & 0.25 \\
\hline Mucinous & 0 & 3 & \\
\hline Serous & 0 & 31 & \\
\hline Clear cell & 1 & 13 & \\
\hline Carcinosarcoma/MMMT & 0 & 13 & \\
\hline Undifferentiated & 0 & 10 & \\
\hline Endometrioid (incl. mucinous) & 37 & 321 & 0.018 \\
\hline Non-endometrioid & 1 & 67 & \\
\hline \multicolumn{4}{|l|}{ Grade } \\
\hline $1 \& 2$ & 34 & 278 & 0.02 \\
\hline 3 & 4 & 110 & \\
\hline \multicolumn{4}{|l|}{ Any MMR deficiency } \\
\hline Negative & 27 & 151 & $<0.0001$ \\
\hline Positive & 10 & 203 & \\
\hline \multicolumn{4}{|l|}{ MRE11 } \\
\hline Negative & 25 & 107 & $<0.0001$ \\
\hline Positive & 11 & 272 & \\
\hline \multicolumn{4}{|l|}{ RAD50 } \\
\hline Negative & 16 & 85 & 0.007 \\
\hline Positive & 20 & 298 & \\
\hline \multicolumn{4}{|l|}{ NBN } \\
\hline Negative & 29 & 98 & $<0.0001$ \\
\hline Positive & 7 & 282 & \\
\hline \multicolumn{4}{|l|}{ MRN complex } \\
\hline Negative & 30 & 137 & $<0.0001$ \\
\hline Positive & 6 & 241 & \\
\hline
\end{tabular}

MMMT: Malignant mixed Müllerian tumor; MMR: mismatch repair.

damage-induced foci involve other important proteins such as tumour protein $\mathrm{p} 53$ binding protein 1 (TP53BP1), BRCA1 and the heterotrimeric MRN complex (37).

To our knowledge, this is the first report to show the role of MDC1 protein in samples of human EC. Our studies show that the expression of MDC1 protein is lost in a notable proportion of ECs $(8.9 \%)$. In a previous study, we investigated the MMR protein status (MLH1, MSH2, MSH6, PMS2) and MRN complex proteins MRE11, RAD50, and NBS in this EC cohort (22). Since MDC1 plays a role in DNA repair, we were interested in an association between MDC1 and MMR, as well as MRN status. We observed an association between loss of MDC1 and MMR protein deficiency as well as loss of nuclear protein expression of the evaluated MRN complex proteins which suggests that MDC1 loss is a frequent occurrence in MMR-deficient ECs (hypermutated subgroup). 
Previous studies verified that tumour cells with impaired HR DNA-repair exhibit increased sensitivity to PARP inhibitors. The therapeutic benefit of PARP inhibitors in germline BRCA1/2-deficient tumours, such as breast, ovarian, pancreatic and prostate cancers has been proven in vitro as well as in clinical trials (38-41). For EC, the synthetic lethal interaction between MRE11 and PARP1, was demonstrated in vitro with PARP inhibitors (22). Furthermore, the loss of PTEN, which is the most commonly affected gene in endometrioid ECs (42), sensitizes cancer cell lines to PARP-inhibitory treatment (43) although the exact function of PTEN in homologous recombination is not clearly defined. Various studies have suggested that loss of MDC1 might be associated with a favourable prognosis. Recently, Wang et al. showed that MDC1-depletion combined with PARP inhibition can enhance the sensitivity of olaparib in nasopharyngeal carcinoma. MDC1-deficient cells also revealed a decrease of BRCA1, BRCA2 and RAD51, which is suggestive of a direct inhibit of HRmediated DNS repair through impairment of neighboring foci. The down-regulation of MDC1 led to defective HR through blockage of DNA damage-repair proteins (44).

Based on these findings, we conclude that loss of MDC1 expression occurs in a notable proportion of ECs, is more common in low-grade endometrioid EC than in nonendometrioid EC, and is associated with MMR deficiency. Due to deficient HR DNA repair, we postulate that tumours with loss of MDC1 might have increased sensitivity to PARP inhibitor therapy. The effect of MDC1-negative ECs on sensitivity to PARP inhibitor in EC has not yet been proven and needs further investigation.

\section{Conflicts of Interest}

The Authors declare that no conflict of interest exists in regard to this study.

\section{Authors' Contributions}

Conceived and designed the experiments: KJD SB. Performed the experiments: SB AN. Analyzed the data: SB AN KJD EPS DM. Contributed reagents/materials/analysis tools: SB AN KJD. Wrote the article: DM, BN, EPS, KJD SB AN.

\section{References}

1 Cramer DW: The epidemiology of endometrial and ovarian cancer. Hematol Oncol Clin North Am 26(1): 1-12, 2012. PMID: 22244658. DOI: 10.1016/j.hoc.2011.10.0009

2 Siegel RL, Miller KD and Jemal A: Cancer statistics, 2018. CA Cancer J Clin 68(1): 7-30, 2018. PMID: 29313949. DOI: $10.3322 /$ caac. 21442

3 Sheikh MA, Althouse AD, Freese KE, Soisson S, Edwards RP, Welburn S, Sukumvanich P, Comerci J, Kelley J, LaPorte RE and Linkov F: USA endometrial cancer projections to 2030: Should we be concerned? Future Oncol 10(16): 2561-2568, 2014. PMID: 25531045. DOI: $10.2217 /$ fon. 14.192

4 Dellinger TH and Monk BJ: Systemic therapy for recurrent endometrial cancer: A review of North American trials. Expert Rev Anticancer Ther 9(7): 905-916, 2009. PMID: 19589030. DOI: $10.1586 /$ era.09.54

5 Barrington DA, Dilley SE, Smith HJ and Straughn JM: Pembrolizumab in advanced recurrent endometrial cancer: A cost-effectiveness analysis. Gynecol Oncol 153(2): 381-384, 2019. PMID: 30808517. DOI: 10.1016/j.ygyno.2019.02.013

6 Le DT, Durham JN, Smith KN, Wang H, Bartlett BR, Aulakh LK, Lu S, Kemberling H, Wilt C, Luber BS, Wong F, Azad NS, Rucki AA, Laheru D, Donehower R, Zaheer A, Fisher GA, Crocenzi TS, Lee JJ, Greten TF, Duffy AG, Ciombor KK, Eyring AD, Lam BH, Joe A, Kang SP, Holdhoff M, Danilova L, Cope L, Meyer C, Zhou S, Goldberg RM, Armstrong DK, Bever KM, Fader AN, Taube J, Housseau F, Spetzler D, Xiao N, Pardoll DM, Papadopoulos N, Kinzler KW, Eshleman JR, Vogelstein B, Anders RA and Diaz LA: Mismatch repair deficiency predicts response of solid tumors to PD-1 blockade. Science 357(6349): 409-413, 2017. PMID: 28596308. DOI: $10.1126 /$ science.aan6733

7 Bokhman JV: Two pathogenetic types of endometrial carcinoma. Gynecol Oncol 15(1): 10-17, 1983. PMID: 6822361. DOI: 10.1016/0090-8258(83)901111-7

8 Hecht JL and Mutter GL: Molecular and pathologic aspects of endometrial carcinogenesis. J Clin Oncol 24(29): 4783-4791, 2006. PMID: 17028294. DOI: 10.1200/JCO.2006.06.7173

9 Dedes KJ, Wetterskog D, Ashworth A, Kaye SB and Reis-Filho JS: Emerging therapeutic targets in endometrial cancer. Nat Rev Clin Oncol 8(5): 261-271, 2011. PMID: 21221135. DOI: 10.1038/nrclinonc.2010.216

10 Fujimoto T, Nanjyo H, Fukuda J, Nakamura A, Mizunuma H, Yaegashi N, Sugiyama T, Kurachi H, Sato A and Tanaka T: Endometrioid uterine cancer: Histopathological risk factors of local and distant recurrence. Gynecol Oncol 112(2): 342-347, 2009. PMID: 19062082. DOI: 10.1016/j.ygno.2008.10.019

11 Lax SF, Pizer ES, Ronnett BM and Kurman RJ: Comparison of estrogen and progesterone receptor, Ki-67, and p53 immunoreactivity in uterine endometrioid carcinoma and endometrioid carcinoma with squamous, mucinous, secretory, and ciliated cell differentiation. Hum Pathol 29(9): 924-931, 1998. PMID: 9744308. DOI: 10.1016/s0046-8177(98)90197-6

12 Cirisano FD, Robboy SJ, Dodge RK, Bentley RC, Krigman HR, Synan IS, Soper JT and Clarke-Pearson DL: Epidemiologic and surgicopathologic findings of papillary serous and clear cell endometrial cancers when compared to endometrioid carcinoma. Gynecol Oncol 74(3): 385-394, 1999. PMID: 10479498. DOI: 10.1006/gyno.1999.5505

13 Hamilton CA, Cheung MK, Osann K, Chen L, Teng NN, Longacre TA, Powell MA, Hendrickson MR, Kapp DS and Chan JK: Uterine papillary serous and clear cell carcinomas predict for poorer survival compared to grade 3 endometrioid corpus cancers. Br J Cancer 94(5): 642-646, 2006. PMID: 16495918. DOI: $10.1038 / \mathrm{sj}$. bjc.6603012

14 Lax SF, Kendall B, Tashiro H, Slebos RJ and Hedrick L: The frequency of $p 53, K-R A S$ mutations, and microsatellite instability differs in uterine endometrioid and serous carcinoma: Evidence of distinct molecular genetic pathways. Cancer 88(4): 814-824, 2000. PMID: 10679651. 
15 Tashiro H, Isacson C, Levine R, Kurman RJ, Cho KR and Hedrick L: P53 gene mutations are common in uterine serous carcinoma and occur early in their pathogenesis. Am J Pathol 150(1): 177-185, 1997. PMID: 9006334.

16 Kandoth C, Schultz N, Cherniack AD, Akbani R, Liu Y, Shen H, Robertson AG, Pashtan I, Shen R, Benz CC, Yau C, Laird PW, Ding L, Zhang W, Mills GB, Kucherlapati R, Mardis ER, Levine DA and Network CGAR: Integrated genomic characterization of endometrial carcinoma. Nature 497(7447): 67-73, 2013. PMID: 23636398. DOI: 20/1028/nature 12113

17 Bilbao C, Ramírez R, Rodríguez G, Falcón O, León L, DíazChico N, Perucho M and Díaz-Chico JC: Double-strand break repair components are frequent targets of microsatellite instability in endometrial cancer. Eur J Cancer 46(15): 28212827, 2010. PMID: 20638839. DOI: 10.1016/j.ejca.2010.06.116

18 Hartwell LH, Szankasi P, Roberts CJ, Murray AW and Friend $\mathrm{SH}$ : Integrating genetic approaches into the discovery of anticancer drugs. Science 278(5340): 1064-1068, 1997. PMID: 9353181. DOI: $10.1126 /$ science.278.5340.1064

19 Bridges CB: The origin of variation. Amer Nat 56: 51-63, 1922.

20 Brough R, Frankum JR, Costa-Cabral S, Lord CJ and Ashworth A: Searching for synthetic lethality in cancer. Curr Opin Genet Dev 21(1): 34-41, 2011. PMID: 21255997. DOI: 10.1016/j.gde.2010.10.009

21 Kaelin WG: The concept of synthetic lethality in the context of anticancer therapy. Nat Rev Cancer 5(9): 689-698, 2005. PMID: 16110319. DOI: $10.1038 /$ nrc 1691

22 Koppensteiner R, Samartzis EP, Noske A, von Teichman A, Dedes I, Gwerder M, Imesch P, Ikenberg K, Moch H, Fink D, Stucki M and Dedes KJ: Effect of MRE11 loss on PARP-inhibitor sensitivity in endometrial cancer in vitro. PLoS One 9(6): e100041, 2014. PMID: 24927325. DOI: 10.1371/journal.pone.0100041

23 Dedes KJ, Wilkerson PM, Wetterskog D, Weigelt B, Ashworth A and Reis-Filho JS: Synthetic lethality of PARP inhibition in cancers lacking BRCA1 and BRCA2 mutations. Cell Cycle 10(8): 1192-1199, 2011. PMID: 21487248. DOI: $10.4161 / \mathrm{cc} .10 .8 .15273$

24 Ashworth A: A synthetic lethal therapeutic approach: Poly(ADP) ribose polymerase inhibitors for the treatment of cancers deficient in DNA double-strand break repair. J Clin Oncol 26(22): 37853790, 2008. PMID: 18591545. DOI: 10.1200/JCO.2008.16.0812

25 Stracker TH and Petrini JH: The mre11 complex: Starting from the ends. Nat Rev Mol Cell Biol 12(2): 90-103, 2011. PMID: 21252998. DOI: $10.1038 / \mathrm{nrm} 3047$

26 Lamarche BJ, Orazio NI and Weitzman MD: The MRN complex in double-strand break repair and telomere maintenance. FEBS Lett 584(17): 3682-3695, 2010. PMID: 20655309. DOI: 10.1016/j.febslet.2010.07.029

27 Dimitrova N and de Lange T: MDC1 accelerates nonhomologous end-joining of dysfunctional telomeres. Genes Dev 20(23): 32383243, 2006. PMID: 17158742. DOI: 10.1101/gad.1496606

28 Zhang J, Ma Z, Treszezamsky A and Powell SN: MDC1 interacts with RAD51 and facilitates homologous recombination. Nat Struct Mol Biol 12(10): 902-909, 2005. PMID: 16186822. DOI: $10.1038 / \mathrm{nsmb} 991$

29 Wild PJ, Ikenberg K, Fuchs TJ, Rechsteiner M, Georgiev S, Fankhauser N, Noske A, Roessle M, Caduff R, Dellas A, Fink D, Moch H, Krek W and Frew IJ: P53 suppresses type II endometrial carcinomas in mice and governs endometrial tumour aggressiveness in humans. EMBO Mol Med 4(8): 808-824, 2012. PMID: 22678923. DOI: 10.1002/emmm.201101063
30 Heeke AL, Pishvaian MJ, Lynce F, Xiu J, Brody JR, Chen WJ, Baker TM, Marshall JL and Isaacs C: Prevalence of homologous recombination-related gene mutations across multiple cancer types. JCO Precis Oncol 2018: 2018. PMID: 30234181. DOI: 10.1200/PO.17.00286

31 Chartron E, Theillet C, Guiu S and Jacot W: Targeting homologous repair deficiency in breast and ovarian cancers: Biological pathways, preclinical and clinical data. Crit Rev Oncol Hematol 133:58-73, 2019. PMID: 30661659. DOI: 10.1016/j.critrevonc.2018.10.012

32 Lou Z, Minter-Dykhouse K, Franco S, Gostissa M, Rivera MA, Celeste A, Manis JP, van Deursen J, Nussenzweig A, Paull TT, Alt FW and Chen J: MDC1 maintains genomic stability by participating in the amplification of ATM-dependent DNA damage signals. Mol Cell 21(2): 187-200, 2006. PMID: 16427009. DOI: $10.1016 /$ j.molcel.2005.11.025

33 Bartkova J, Horejsí Z, Sehested M, Nesland JM, Rajpert-De Meyts E, Skakkebaek NE, Stucki M, Jackson S, Lukas J and Bartek J: Dna damage response mediators MDC1 and 53BP1: Constitutive activation and aberrant loss in breast and lung cancer, but not in testicular germ cell tumours. Oncogene 26(53): 7414-7422, 2007. PMID: 17546051. DOI: 10.1038/ sj.onc. 1210553

34 Zhang ZZ, Liu YJ, Yin XL, Zhan P, Gu Y and Ni XZ: Loss of BRCA1 expression leads to worse survival in patients with gastric carcinoma. World J Gastroenterol 19(12): 1968-1974, 2013. PMID: 23569353. DOI: 10.3748/wjg.v19.i12.1968

35 Stewart GS, Wang B, Bignell CR, Taylor AM and Elledge SJ: MDC1 is a mediator of the mammalian DNA damage checkpoint. Nature 421(6926): 961-966, 2003. PMID: 12607005. DOI: $10.1038 /$ nature 01446

36 Goldberg M, Stucki M, Falck J, D'Amours D, Rahman D, Pappin D, Bartek $\mathrm{J}$ and Jackson SP: MDC1 is required for the intra-S-phase DNA damage checkpoint. Nature 421(6926): $952-$ 956, 2003. PMID: 12607003. DOI: 10.1038/nature01445

37 Lou Z, Minter-Dykhouse K, Wu X and Chen J: Mdc1 is coupled to activated CHK2 in mammalian DNA damage response pathways. Nature 421(6926): 957-961, 2003. PMID: 12607004. DOI: 10.1038 /nature01447

38 Fong PC, Boss DS, Yap TA, Tutt A, Wu P, Mergui-Roelvink M, Mortimer P, Swaisland H, Lau A, O'Connor MJ, Ashworth A, Carmichael J, Kaye SB, Schellens JH and de Bono JS: Inhibition of poly(ADP-ribose) polymerase in tumors from $B R C A$ mutation carriers. N Engl J Med 361(2): 123-134, 2009. PMID: 19553641. DOI: 10.1056/NEJMoa0900212

39 Lowery MA, Kelsen DP, Stadler ZK, Yu KH, Janjigian YY, Ludwig E, D'Adamo DR, Salo-Mullen E, Robson ME, Allen PJ, Kurtz RC and O'Reilly EM: An emerging entity: Pancreatic adenocarcinoma associated with a known BRCA mutation: Clinical descriptors, treatment implications, and future directions. Oncologist 16(10): 1397-1402, 2011. PMID: 21934105. DOI: 10.1634/theoncologist.2011-0185

40 Tutt A, Robson M, Garber JE, Domchek SM, Audeh MW, Weitzel JN, Friedlander M, Arun B, Loman N, Schmutzler RK, Wardley A, Mitchell G, Earl H, Wickens M and Carmichael J: Oral poly(ADP-ribose) polymerase inhibitor olaparib in patients with $B R C A 1$ or $B R C A 2$ mutations and advanced breast cancer: A proof-of-concept trial. Lancet 376(9737): 235-244, 2010. PMID: 20609467. DOI: $10.1016 /$ S0140-6736(10)60892-6 
41 Audeh MW, Carmichael J, Penson RT, Friedlander M, Powell B, Bell-McGuinn KM, Scott C, Weitzel JN, Oaknin A, Loman N, Lu K, Schmutzler RK, Matulonis U, Wickens M and Tutt A: Oral poly(ADP-ribose) polymerase inhibitor olaparib in patients with $B R C A 1$ or $B R C A 2$ mutations and recurrent ovarian cancer: A proof-of-concept trial. Lancet 376(9737): 245-251, 2010 PMID: 20609468. DOI: 10.1016/S0140-6736(10)60893-8

42 Mutter GL, Lin MC, Fitzgerald JT, Kum JB, Baak JP, Lees JA, Weng LP and Eng C: Altered PTEN expression as a diagnostic marker for the earliest endometrial precancers. J Natl Cancer Inst 92(11): 924-930, 2000. PMID: 10841828. DOI: 10.1093/ jnci/92.11.924

43 Forster MD, Dedes KJ, Sandhu S, Frentzas S, Kristeleit R, Ashworth A, Poole CJ, Weigelt B, Kaye SB and Molife LR: Treatment with olaparib in a patient with PTEN-deficient endometrioid endometrial cancer. Nat Rev Clin Oncol 8(5): 302306, 2011. PMID: 21468130. DOI: 10.1038/nrclinonc.2011.42
44 Wang Z, Zuo W, Zeng Q, Qian Y, Li Y, Liu C, Wang J, Zhong $\mathrm{S}, \mathrm{Bu} \mathrm{Y}$ and $\mathrm{Hu} \mathrm{G}$ : Loss of NFBD1/MDC1 disrupts homologous recombination repair and sensitizes nasopharyngeal carcinoma cells to PARP inhibitors. J Biomed Sci 26(1): 14, 2019. PMID: 30717758. DOI: 10.1186/s12929-019-0507-z
Received October 2, 2019

Revised November 3, 2019 Accepted November 6, 2019 